\title{
Engaging Communities in Emergency Risk and Crisis Communication: A Systematic Review and Evidence Synthesis
}

\author{
Julie M. Novak (D), a Ashleigh M. Day, ${ }^{a}$ Pradeep Sopory, ${ }^{a}$ \\ Lee Wilkins, ${ }^{a}$ Donyale Padgett, ${ }^{a}$ Stine Eckert, ${ }^{a}$ Jane \\ Noyes, ${ }^{b}$ Tomas Allen, ${ }^{c}$ Nyka Alexander, ${ }^{c}$ Marsha \\ Vanderford, ${ }^{c}$ and Gaya Gamhewage ${ }^{c}$
}

aDepartment of Communication, Wayne State University, Detroit, Michigan, USA; 'bchool of Health Sciences, Bangor University, Bangor, Wales; 'World Health Organization, Geneva, Switzerland

\begin{abstract}
The World Health Organization (WHO) commissioned systematic reviews to assist with the development of new emergency risk communication guidelines that will impact responses and distribution of resources at all levels. This mixed-method evidence synthesis, guided by Cochrane principles and methods, examined the extant research in countries throughout the world, published from 2003 to 2016, related to the best practices to engage communities in preparing for and responding to emergency events with public health implications. Although few studies directly examined which strategies or tactics effectively engage public participation, many studies reinforced the importance of community participation. The findings support the perspective that emergency events are communicatively understood by all publics and that they benefit from emergency risk communication before, during, and after such events, especially when grounded in local contexts. Although the importance of local context limits the generalizability of risk communication, it is important to continue studying strategies and tactics to cultivate participation among all stakeholders.
\end{abstract}

KEYWORDS: Community engagement; crisis; emergency risk communication

Disaster and emergency events with public health implications are identified and understood by publics through communication, messages, and interactions (words label and help define concrete realities) and, therefore, are powerfully shaped by emergency risk communication before, during, and after such events (Centers for Disease Control

CONTACT Julie M. Novak•E-mail:jmnovak@wayne.edu•Department of Communication, Wayne State University, Detroit, MI 48202, USA

๑ 2019 by Journal of International Crisis and Risk Communication Research. All rights reserved. 
and Prevention [CDC], 2014, 2018). Many public health agencies at multiple levels-local, state, regional, national, and internationaloperate organizational divisions dedicated to planning, preparedness, response, and recovery related to emergency events. These hierarchical agencies directly communicate and interact with relevant publics and must effectively coordinate efforts within their organizations as well as interorganizationally (CDC, 2014, 2018). Thus, the World Health Organization (WHO), as an agency of the United Nations (UN), commissioned 12 systematic reviews and evidence-based syntheses to inform the development of WHO Risk Communication Guidelines on Emergency Risk Communication. The question of interest for this systematic review-synthesis was, what are the best ways to engage communities in emergency risk communication activities to respond to events/contexts?

Prior to identifying data-based primary studies, we conducted a search for related literature reviews. The search uncovered 12 existing reviews regarding the focus of inquiry. All were narrative; none were quantitative meta-analyses. Although we did not conduct a structured review of these existing reviews nor extract detailed findings from them, we appraised their relevancy using the criteria in Noyes et al. (2019) and quality using a modified Assessment of Multiple Systematic Reviews (AMSTAR) checklist (Shea et al., 2007). Seven were of moderate quality and subsequently analyzed for summary findings (Gurabardhi, Gutteling, \& Kuttschreuter, 2005; Lettieri, Masella, \& Radaelli, 2009; Levac, Toal-Sullivan, \& O’Sullivan, 2012; McCaffrey, 2015; Savoia, Lin, \& Viswanath, 2013; Schiavo, Leung, \& Brown, 2014; Wachinger, Renn, Begg, \& Kuhlicke, 2013).

These existing reviews focused on risk communication $(n=3)$, emergency/disaster preparedness $(n=2)$, disaster management $(n=1)$, and risk perception $(n=1)$ for a variety of emergency events, including disasters in general, emergent infectious diseases, natural disasters, industrial hazards, and technological hazards. They predominantly drew from studies on events in the developed world, particularly in the United States/Canada, Western Europe, and Australia. Only one review focused on low- to moderate-income countries and reported inconclusive findings due to a paucity of studies.

The summary of review findings revealed first that how best to en- 
gage communities in activities is rarely of direct focus of inquiry and minimally examined. Second, community is not a universally defined concept. Third, public participation, in general, is associated with improved preparedness/response actions. And, fourth, most studies continue to place extensive focus on individual and contextual factors in relation to household/community emergency preparedness rather than community engagement/participation in emergency activities. Therefore the purpose of this systematic review is to identify evidencebased studies published since 2003 that query the best ways to engage communities in emergency risk communication activities to respond to disaster/emergency events. We provide an extensive explanation of the methodology employed to conduct the systematic review, and following a discussion of the results, we identify gaps in the literature, practice recommendations that are grounded in the evidence synthesis, and suggestions for future research that will enhance and extend practice guidelines.

\section{Method}

This systematic review-synthesis includes data-based primary studies of quantitative, qualitative, and mixed-method/case study approaches conducted throughout the world and reported in English as well as other UN languages, including Arabic, Chinese, French, Russian, and Spanish, from 2003 to 2016, as specified by WHO. Our approach and process drew from principles and guidelines in the Cochrane Handbook and by the Cochrane Qualitative and Implementation Methods Group (Higgins \& Green, 2011). Figure 1 presents the overall design for the evidence synthesis.

\section{Systematic Review Process}

Literature search. We employed a two-phase strategy for literature searching. We conducted a general search, intentionally broad in scope, followed by a narrow search focused on the WHO question. Figure 2 shows the wide range of search terms. After a general search using the Wayne State University Library Summon function, we searched within individual databases (e.g., Web of Science, PubMed/Medline- 


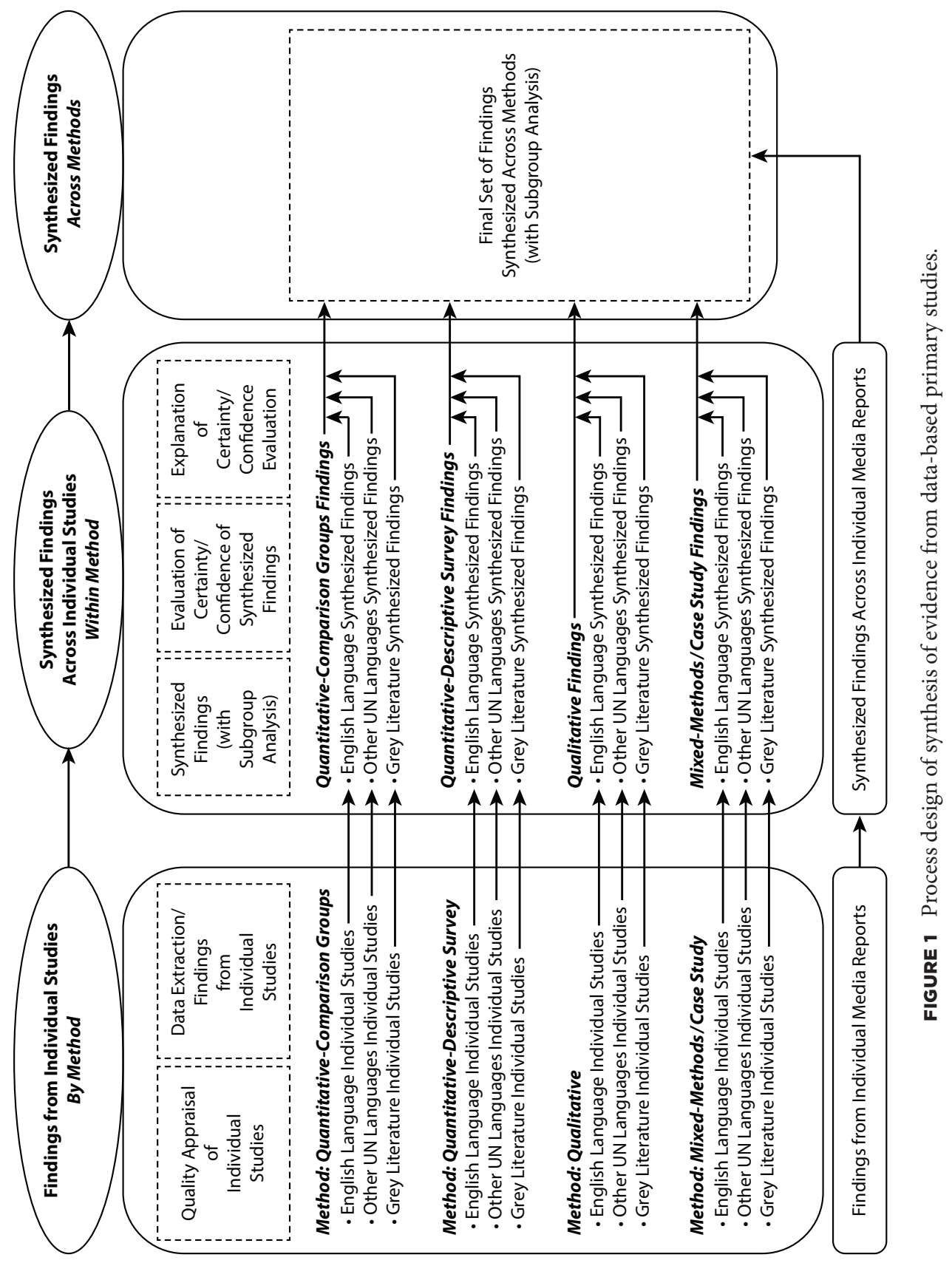




\begin{tabular}{|c|c|}
\hline Disaster* & Community/community at large \\
\hline Disaster plan* & Emergency management \\
\hline Communication & Trust \\
\hline Risk communication & Resilience \\
\hline Emergenc* & Mental health \\
\hline Hazard* & Public health \\
\hline eRisk* & Non-government (various) \\
\hline Threat* & Disaster/emergency/crisis response \\
\hline Emergency preparedness & Public response \\
\hline Emergency management & Awareness (public) \\
\hline $\begin{array}{l}\text { Cris!s (or other truncation used in a } \\
\text { specific database: ?,\#) } \\
\text { Crisis communication }\end{array}$ & Activity, action \\
\hline Disaster preparedness & Risk prevention \\
\hline Hazard communication & Participation (public, community) \\
\hline Emergency communication & Response/responsiveness \\
\hline Catastrophe communication & Preparedness \\
\hline Health communication & Decision/decision making \\
\hline
\end{tabular}

FIGURE 2 Search terms.

National Library of Medicine [NLM]). Similarly, the article selection process occurred in two stages. First, all literature that was related to disaster/emergency risk communication, the WHO question, and the WHO phenomenon of interest was selected. There were no preliminary conceptual definitions for "best ways" (neither strategy nor tactic), community, or participation. Instead, WHO guided us with documents and ongoing consultation to keep the scope broad. They requested, reviewed, and provided feedback on periodic reports and rapid knowledge maps that documented the literature search process in real time. Second, this literature was narrowed to select only relevant data-based primary study articles using quantitative, qualitative, or mixed-method/case study methodologies. 
The search for grey literature, in all languages, used Google Scholar and general Google search as the primary information sources. Grey literature similarly had to be relevant data-based primary study articles using quantitative, qualitative, or mixed-method/case study methodologies. Such articles, however, were not published in academic, refereed journals or indexed by library databases. In addition, an experienced librarian at the National Hazards Center library at the University of Colorado-Boulder, United States, conducted a search specifically for grey literature in close consultation with a team member who was physically present. As shown in Figure 1, these grey literature studies were treated similarly to the academic primary studies.

For articles in English, the search and selection stages were conducted by an experienced librarian with subject-matter expertise and primary members of the research team. For articles in other UN languages, fluent readers and writers of these languages assisted with respective search and selection. Additionally, searches utilized some language-specific databases. All team members participated in norming and training sessions, which were done in a group setting, for search, selection, appraisal, and extraction tasks.

For all resultant articles in the literature search, relatively broad inclusion criteria were employed. Research related to the practice of risk communication and the process of disaster management-with no preference for any specific emergency or health hazards-was included. Additionally, research within the viewpoint or scope set by the risk communication field (e.g., trust, uncertainty, communities, health, misinformation, social/media, and messages) was included. Exclusion criteria consisted of research published previous to 2003, research in organizational risk communication and disaster management (e.g., technological failures), and research outside of the scope of the study, like laboratory studies.

Article appraisal. We appraised the quality of individual quantitative primary studies by using the Effective Practice and Organization of Care (EPOC; 2015) risk of bias tool. This tool provides nine criteria for assessing randomized control trials, nonrandomized control trials, and control before-after studies. Detailed information on the definitions of levels of risk used in this tool is available in Section 12.2.2 of 
the Cochrane Handbook. An adapted version of Davids and Roman's (2014) quality appraisal criteria was also used to appraise quantitative primary studies. This tool assessed on a 2-point scale ranging from 0 (not reported) to 1 (reported) the following areas: sampling, response rate, validity and reliability, sources of data, content and focus of study, and relevancy to the corresponding question. Final ratings were determined by percentage: weak (o\%-33.9\%), moderate (34\%-66.9\%), and strong $(67 \%-100 \%)$. We appraised individual qualitative studies by using the Critical Appraisal Skills Programme (CASP; 2013). CASP assesses appropriateness of qualitative methodology, data collection, relationship between researcher and participants, ethics, rigor of data analysis, clarity of findings, and value of research. Each area in CASP is assessed using "yes," "no," or "can't tell." Studies received a final rating of high (no significant flaws), moderate (minor flaws impacting credibility/validity), low (some flaws likely to impact credibility/validity), or very low (significant flaws impacting credibility/validity). For mixed-method/case studies, we utilized Pluye and colleagues' (2011) Mixed Methods Appraisal Tool (MMAT), which assesses the employed methods and methodological quality. Each area in MMAT is assessed using "yes," "no," or "can't tell." Studies received a final rating of high (no significant flaws), moderate (minor flaws impacting credibility/ validity), low (some flaws likely to impact credibility/validity), or very low (significant flaws impacting credibility/validity).

Two team members (the two lead authors) individually assessed the quality of all relevant articles. After the appraisals were complete, they were reviewed by the principal investigator (the third author). Assessing team members reviewed any conflicts by revisiting the article under question together and discussing each part of the applicable appraisal tool in relation to the article. Conflicts and general results of quality appraisals also were discussed as a team at weekly meetings.

Data extraction. The following study characteristics were extracted from individual data-based primary studies of all method types: method, country focus, disaster/emergency type, disaster/emergency phase, and any at-risk/vulnerable populations. To extract the findings, we used the general process of reading and rereading the abstract, results/findings/analysis, and discussion and conclusion sections to 
isolate the findings of interest. We did this process for all methodological streams: quantitative-comparison groups (QN-CG), quantitativedescriptive survey (QN-DS), qualitative (QL), and mixed-method/ case study (MM, CS).

A quantitative meta-analysis was not suitable due to the very small number of studies that used comparison groups (randomized or nonrandomized). As such, as recommended in Section 11.7.2 of the Cochrane Handbook, dealing with results without meta-analyses, we followed a narrative summary approach to extract findings from studies in all four methodological streams. Quantitative and qualitative evidentiary support for each finding was extracted. The two lead authors completed data extraction, which was also reviewed by the third author. Any disagreements between team members and extracted findings were reviewed by team members by revisiting the article/extraction under question together. A codebook for extracting study characteristics and findings was developed and revised with expert input and feedback.

Data synthesis. The synthesis of findings was done in two stages, as presented in the process design (see Figure 1). In the first stage, findings from individual studies were synthesized within methodological streams, and then these within-method synthesized findings were evaluated for certainty/confidence using appropriate tools (e.g., GRADE, GRADE-CERQual). In the second stage, the within-method synthesized findings were synthesized across methodological streams, taking into account the certainty/confidence evaluations. Whenever the findings from within yet different methodological streams supported and amplified each other, they were combined into higher order findings that represented synthesis across the method streams. The evaluation of certainty in the within-method synthesized findings was kept in mind during this process. Very few synthesized findings within a methodological stream provided evidence that countered the synthesized findings from other methodological streams. Whenever this happened, we strived to retain this finding as a separate finding in the final set of across-method findings or used it to modify an existing across-method finding. In both the within-method and across-method stages, the synthesis of findings included subgroup analyses. These subgroup analyses included examination of type of emergency event, 
phase of emergency event, country of emergency event, and presence of vulnerable population. The last two subgroups allowed considerations of equity in the synthesized findings.

\section{Results}

\section{Study Characteristics}

The summary study characteristics draw from 71 total studies (including 8 from grey literature) of all UN languages ( 6 in Arabic, 3 in Chinese, 21 in French, 34 in English, 5 in Russian, and 2 in Spanish). Thirty-three of the studies employed quantitative methods, 12 employed qualitative methods, and 26 employed mixed methods/case study approaches. Of this total, 39 were directly/partially relevant, and 32 were indirectly relevant. Given greater team expertise in English versus other UN languages, relevance assessments could not be made similarly across all studies. Nonetheless, even those deemed directly relevant most often compared/discussed community participation to no participation in relation to knowledge or action outcomes rather than comparing/ discussing types of strategies or tactics employed in relation to community engagement.

In summary, the studies included disasters in countries distributed throughout the world, which widened the geographical scope (compared to previous reviews) and extended to disaster/emergency events with public health implications. The studies also focused on multiple configurations of phases, although the preparedness phase predominated. There appeared to be an increase in attention to at-risk groups (see Appendixes A and B for characteristics of studies included).

\section{Findings Synthesis}

For the findings synthesis on the best ways to engage communities in emergency risk communication activities to respond to events/contexts, 71 studies were included, appraised for quality, and used for data extraction and formulating synthesized statements within methodological streams, which, in turn, were evaluated for certainty and then synthesized across methodological streams. Again, and extremely noteworthy, the studies rarely examined which ways (including strategies or tactics) 
are most effective for engaging communities. Some studies employed a type of community participation and affirmed its importance yet fell short of rigorously studying the strategy/tactic or testing the efficacy of various strategies/tactics employed to achieve said engagement.

Three related synthesized findings represent findings across all four methodological streams (see Appendix C for a table of all synthesized findings with reference citations). First, meetings prior to an event garner better attendance than those during or after an event. Moreover, meetings prior to an event appear to influence actions related to preparedness and response more effectively than meetings during or after an event. (Note that meetings as an activity is the term used here for all gatherings, including community members, regardless of purpose and implemented agenda.) Second, many studies emphasized and concluded the importance of including some community members in meetings as both planners and attendees. Credible community members as planners are important to include. The purpose of the meetings varied across studies, including plan development, information dissemination, training on roles and responsibilities, and conducting preparedness activities. Third, social relationships and networks stand out in their importance on preparedness and response/recovery actions and are a positive outcome of effective meetings. Meetings secondarily help to develop and sustain relationships characterized by perceptions of credibility, trust, understood role responsibilities, and actions characterized by collaboration and coordination.

Meetings may well be a strategy for achieving a goal of community engagement. Meetings in the reviewed studies varied in purpose and composition of planners, facilitators, and attendees. Example meetings ranged from engaging communities in discussion groups, open forums, educational presentations, and sessions during which families mapped household evacuation routes. Some interventions noted the success of engaging primary and lay health care workers and other credible, trusted community members as planners/facilitators. Of note, training on the roles and responsibilities of each community group (e.g., households, neighborhoods, volunteer groups, organizations) and governmental group appeared to help coordination of efforts. Such focus on differing roles and responsibilities optimally included considerations of 
different (as well as similar) lived contexts and past experiences. Training of this nature also may have helped resolve issues of risk paradox tied to perception and experience, while relationship building and bonding not only served to create trust and confidence in community leaders but also served to create social connectedness and networks.

There are three synthesized findings across three of the four methodological streams. First, disaster/emergency events happen locally. While important for engaging communities in activities, local context also needs to be considered throughout all agenda items and features of an event and at all levels of perspective (QN-DS, QL, MM, CS). Second, risk perception corresponds to individual actions of preparedness for and response to disasters/emergency events. Although the correspondence is frequently positive, there do exist inverse relationships for individuals within a community (QN-CG, QN-DS, MM, CS). Third, when communicating messages to individuals about potential/actual events, the messages are more likely to be persuasive if they are framed and targeted for a specific public, congruent in content, and disseminated through many channels (QN-CG, QN-DS, MM, CS). This also appears true for messages that encourage publics to attend meetings related to potential/actual events.

One synthesized finding across two of four methodological streams (QL, MM, CS) relates partially to the question of study. Access to material resources and technologies impact infrastructure/capacity, participation in activities as well as preparedness and response actions, and innovation/learning from past events.

For more details on individual study findings and synthesized findings within and across methodological streams, see the full report submitted to WHO (2018). The report cites the related studies on which findings are grounded. Additionally, the report contains the certainty/confidence assessments of the synthesized findings within methodological streams.

\section{Discussion}

The present review-synthesis in comparison to the seven preexisting reviews includes evidence-based research conducted in the field 
throughout the world and published in all UN languages. Results from study characteristics reveal an increased scope in relation to the geographical countries of disaster/emergency onset. Most of the studies cited in this review were done in the context of general/multiple types of events $(n=25)$ or floods $(n=19)$. All of the event types in the existing reviews (and more) are represented. Similarly, there is more evidence about the phase(s) of the events studied and multiple configurations of the phases. Like the existing reviews, the studies cited in this review usually approached risk communication as a multidisciplinary phenomenon. The consideration of high-risk and vulnerable populations is more evident in the articles yet still limited as related to the level of need in practice and society.

Emergency events with public health implications happen locally. Including communities is vital. To include community members as planners/facilitators of activities and to engage as many as possible in activities appears to be evidence supported and a best practice. Based on the preceding evidence-based findings synthesis, WHO now guides practitioners responding to potential/actual public health emergencies "to identify people that the community trusts and build relationships with them. Involve them in decision-making to ensure interventions are collaborative, contextually appropriate and that communication is community-owned" (a strong recommendation with moderate quality evidence) (WHO, 2018).

At present, however, there is insufficient evidence as to the "best ways" to engage any local community. The understudied comparison of ways to include the local community or assessments as to what constitutes engagement (participation) during activities likely limits the guideline's utility. Similarly, it is important to note that the undifferentiated concept of "community" remains problematic by not separating findings specifically related to communities-at-large (official leaders) versus community sectors (formal or informal) or community individuals/households (see WHO, 2018, for details on studies with precisely defined community members).

When parsing the question and the phenomenon of interest, it became apparent that concept and word choice matter. Conceptual and semantic differences exist between disciplines as well as research 
and practice paradigms. The creation/use of a typology, prompting more precise classification of the extant research, would (a) provide a visual perspective of the framing of the phenomenon/a of interest, (b) reveal the current knowledge findings/claims, and (c) identify areas in need of future research. Movement toward shared typologies would facilitate more effective and efficient transfer of knowledge and recommendations.

The paucity of directly relevant and high-quality studies likely relates to the preference for publishing outcomes related to community actions after engagement in activities. If such studies had sufficient success in engaging communities, more descriptive detail on the way researchers did engage communities would help to provide rich examples with greater utility. Additionally, WHO's goal for identifying the best ways to engage communities should prompt more researchers to conduct multiples ways of engaging communities within one study. Although the importance of local context may conflict with the goal of generalizable, best ways, descriptive detail about any and all ways of community participation may allow practitioners to better transfer evidence-based findings.

\section{Gaps in the Literature}

The most apparent gap in the literature is the paucity of studies directly related to the phenomenon of interest, effective ways to engage communities in planning activities and activities for preparedness and response actions. As discussed, this becomes even more problematic if recommendations differ for different community levels or different types of engagement because the evidence becomes even sparser. More nuanced definitions of community, such as our proposed categorization of "communities-at-large," "community sectors," and "community individuals/households," would help target and evaluate the pragmatic utility of activities. The gaps only widen when also considering potential differences in optimal activities related to the temporal phases of before, during, and after disaster/emergency events. These gaps require separate attention. 


\section{Limitations of the Present Review}

As noted, there is a paucity of studies directly relevant to the purpose of studying the best ways to engage communities in activities related to disaster/emergency events with public health implications. Therefore much of the search for literature entailed identifying articles partially or indirectly relevant. Three factors clearly obfuscated the search. One, the more detailed explanation of the question for this review provided by the WHO extensions of the question, introduced more ambiguity, rather than less, as to the question's essence. We are uncertain whether parsing through the ambiguities transfers to any theoretical or practical utility for practice. Two, when searching for partially and indirectly related literature, the initial keywords continue to influence the identified literature even with the addition of more keywords. Thus some partially or indirectly relevant bodies of literature may or may not be identified if they have a unique and distinct nomenclature. Finally, the identification/selection of partially or indirectly relevant bodies of literature is impacted by the researchers' judgment as to what constitutes an indirect relationship. For example, the body of accumulating research on the concept and utility of resilience (not included) is arguably indirectly related and potentially as insightful to the question of this review as those of risk perception and risk communication messaging. Additionally, research in other disciplines regarding community-based participatory research, entertainment education, and engaged scholarship is not included. By conducting and reporting on this review in a transparent manner, these limitations are made explicit.

If the objective of this review had been written from a practitioner perspective, some of the difficulties in identifying and reviewing relevant literature may have indicated a lack of translational fluency in phenomena of interest and approaches to address them between practitioners and researchers. Moreover, to the extent that researchers examine problems and phenomena emergent from the field, they may be adding to the problem by code switching in ways that do not improve the two-way transfer of knowledge. 


\section{Conclusions}

Public health emergency events always happen locally in communities. The resulting WHO guideline, informed by this review and synthesis, stresses the need to include community members and to "involve them in decision-making to ensure that interventions are collaborative and contextually appropriate and that the community owns the process of communication" (WHO, 2018, p. 14).

Nevertheless, extant, empirical research has rarely examined the ways (strategies or tactics) that are most effective for engaging community participation. Moreover, attention to and examination of the operational concepts for engagement (participation) and community are limited. Future research is needed to query such topics. Likewise, practitioners will do well to consider WHO guidelines in their entirety and document the many aspects of how they plan for, respond to, and evaluate potential/actual emergency events with public health implications.

For engagement to occur on the local level, participatory research, action research, community organizing, and bottom-up strategies should be explored, especially as they relate to longitudinal outcomes and evaluations. As risks, emergencies, and crises perpetually surround us and are occurring at greater frequencies, building a foundation of evidence-based research on the best ways to engage communities in emergency risk communication activities to respond to crisis and/or emergency events is necessary to protect health and safety. Whenever possible, collaborations between researchers and practitioners may effectively and efficiently maximize resources and coordinate learning from/in the field. 


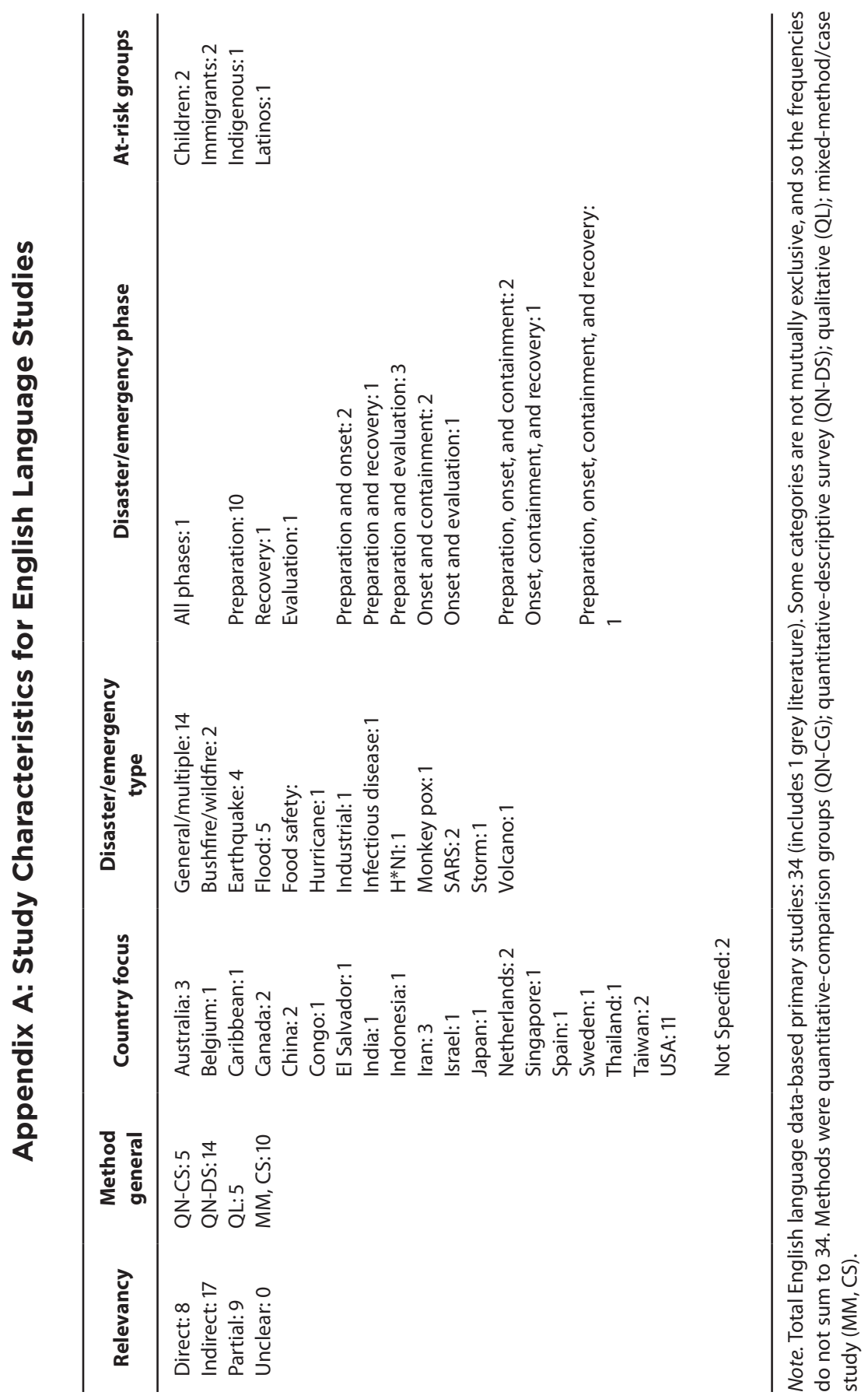




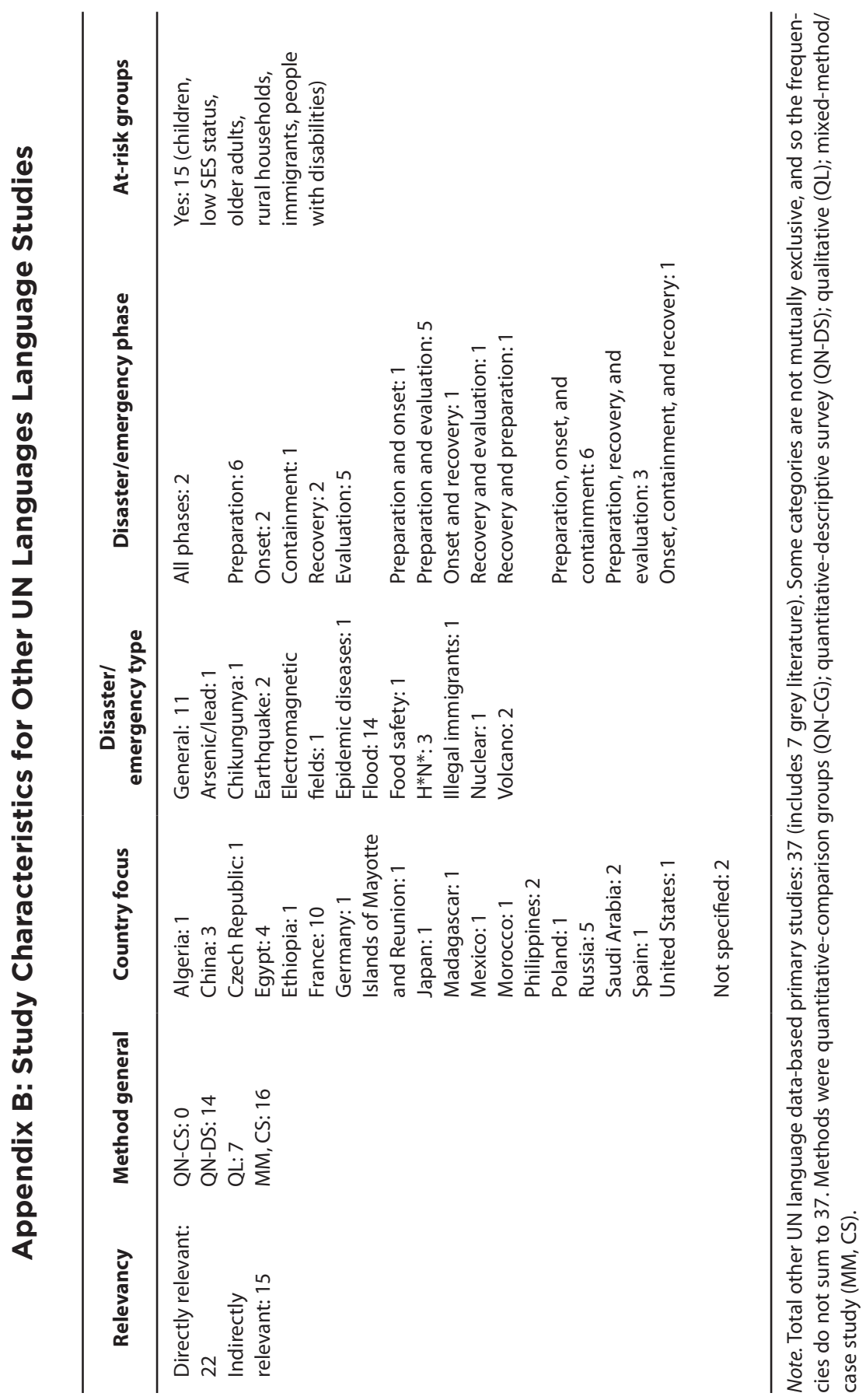




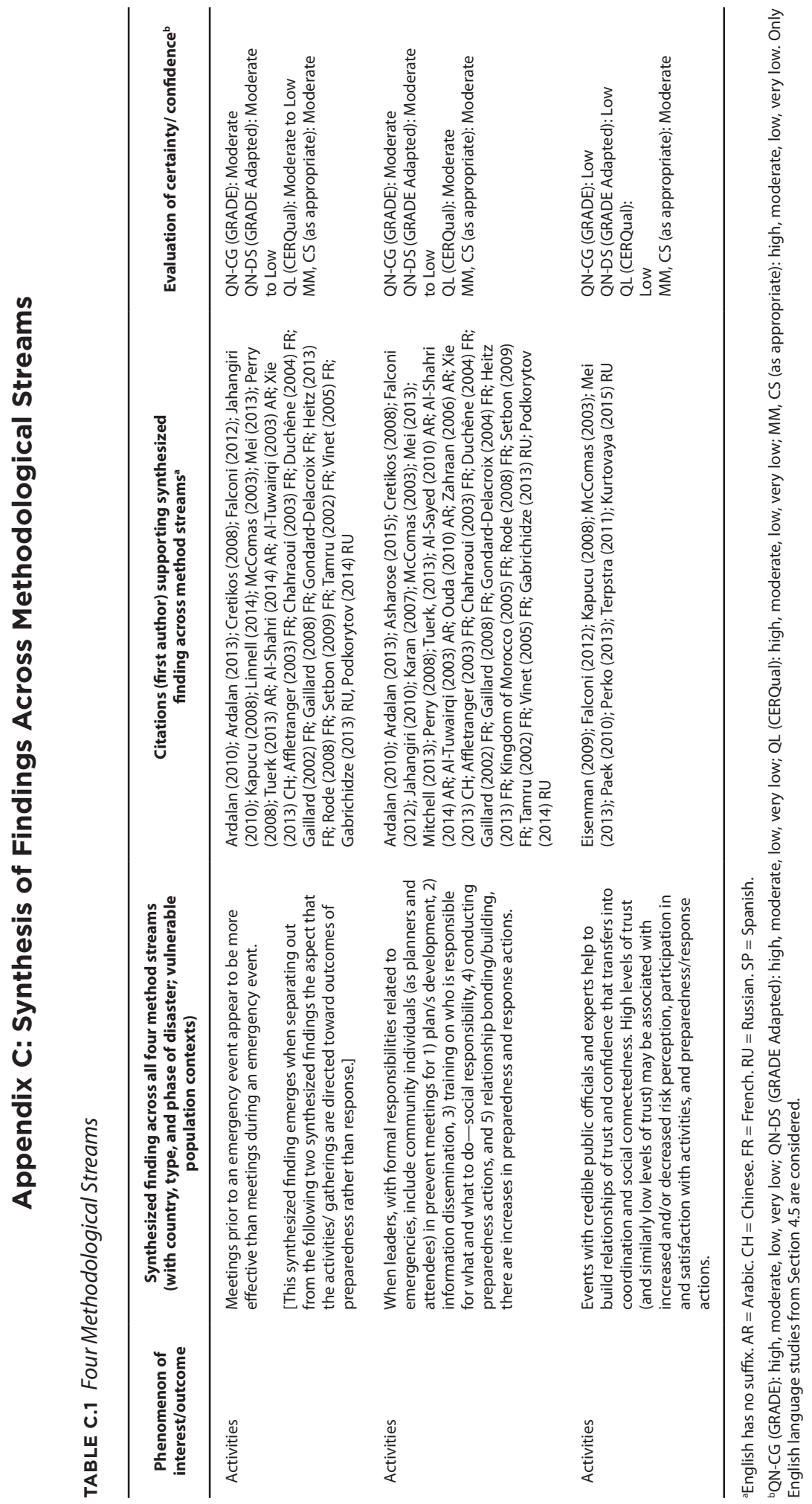




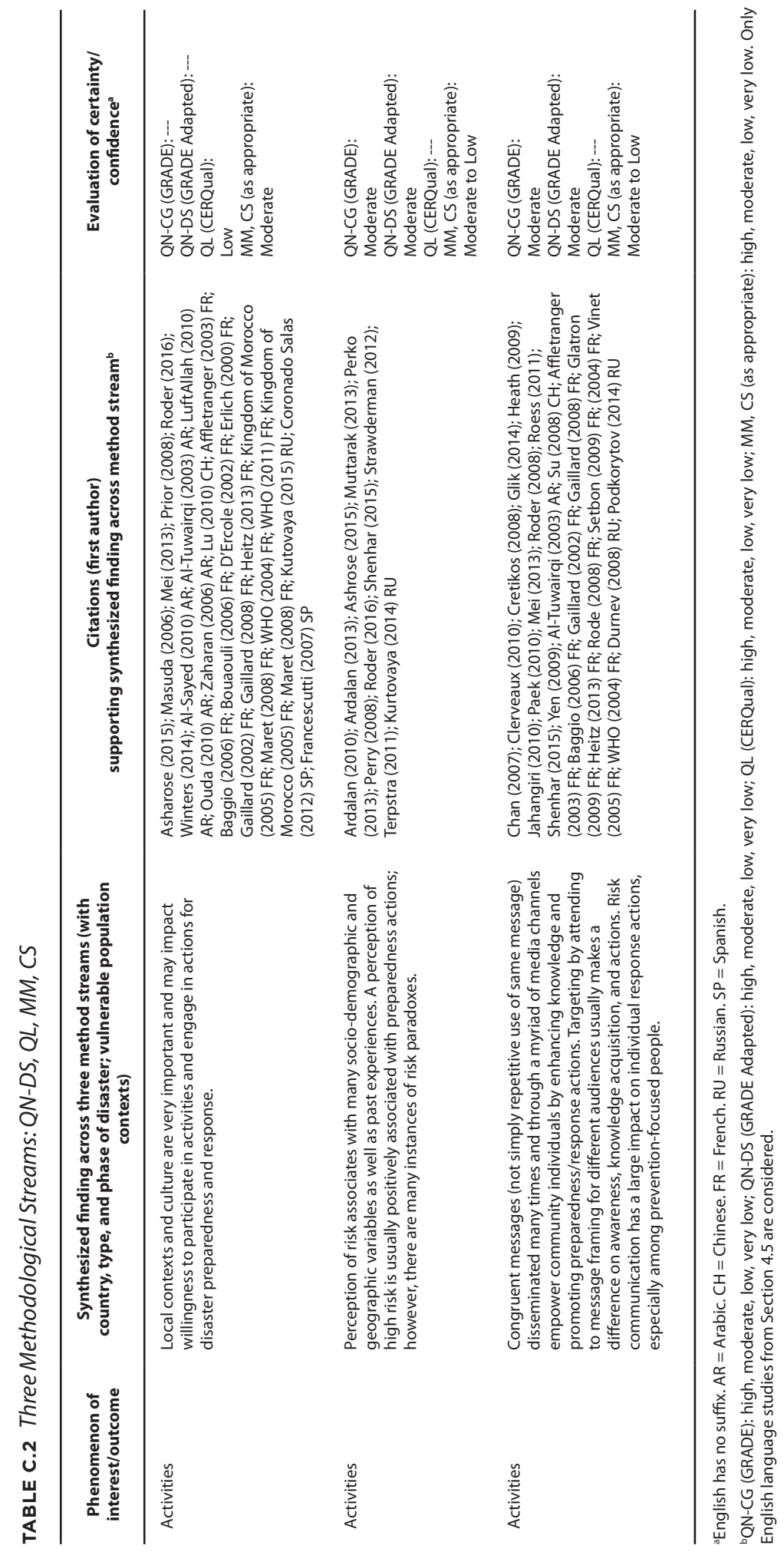




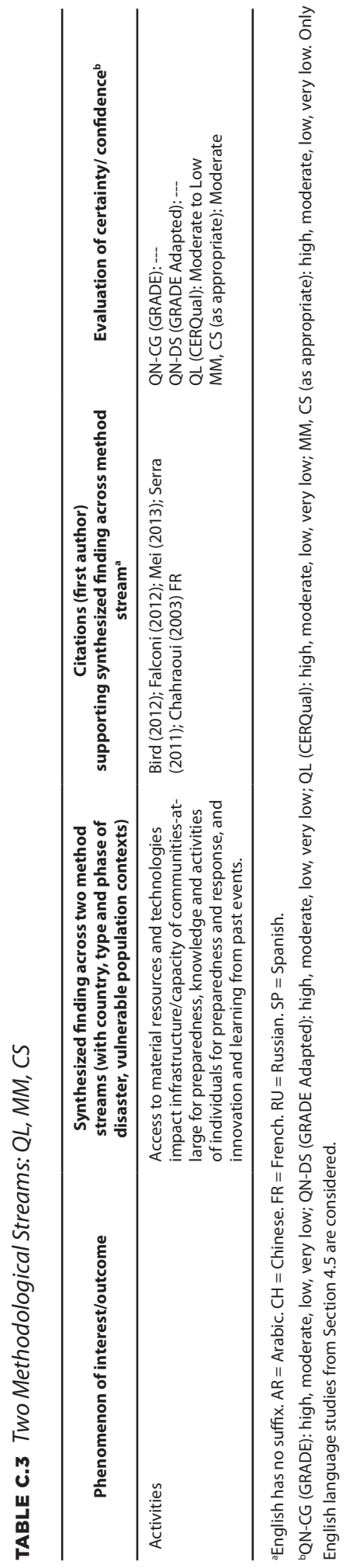




\section{English Language Studies}

Ardalan, A., Naieni, K. H., Mahmoodi, M., Zanganeh, A.-M., Keshtkar, A.-A., Honarvar, M.-R., \& Kabir, M. J. (2010). Flash flood preparedness in Golestan province of Iran: A community intervention trial. American Journal of Disaster Medicine, 5, 197-214. https://doi.org/10.5055/ajdm.2010.0022 Ardalan, A., Mowafi, H., Ardakani, H. M., Abolhasanai, F., Zanganeh, A.-M., Safizadeh, H., ... Zonoobi, V. (2013). Effectiveness of a primary health care program on urban and rural community disaster preparedness, Islamic Republic of Iran: A community intervention trial. Disaster Medicine and Public Health Preparedness, 7, 481-49o. https://doi.org/10.1017/dmp.2013.93

Ashrose, I. S., \& Sasi, R. K. C. (2015). Awareness workshop as an effective tool and approach for education in disaster risk reduction: A case study from Tamil Nadu, India. Sustainability, 7, 8965-84. https://doi.org/10.3390 /su7078965

Bird, D., Ling, M., \& Haynes, K. (2012). Flooding Facebook-the use of social media during the Queensland and Victorian floods. Australian Journal of Emergency Management, 27, 27-33. Retrieved from https://knowledge.aidr .org.au/media/2499/ajem-27-01-09.pdf

Chan, S. S. C., So, W. K. W., Wong, D. C. N., Lee, A. C. K., \& Tiwari, A. (2007). Improving older adults' knowledge and practice of preventive measures through a telephone health education during the SARS epidemic in Hong Kong: A pilot study. International Journal of Nursing Studies, 44, 1120-1127. https://doi.org/10.1016/j.ijnurstu.2006.04.019

Clerveaux, V., Spence, B., \& Katada, T. (2010). Promoting disaster awareness in multicultural societies: The DAG approach. Disease Prevention and Management, 19, 199-218. https://doi.org/10.1108/09653561011038002

Cretikos, M., Eastwood, K., Dalton, C., Merritt, T., Tuyl, F., Winn, L., \& Durrheim, D. (2008). Household disaster preparedness and information sources: Rapid cluster survey after a storm in New South Wales, Australia. BMC Public Health, 8, 195. https://doi.org/10.1186/1471-2458-8-195

Eisenman, D. P., Glik, D., Gonzalez, L., Maranon, R., Zhou, Q., Tseng, C.-H., $\&$ Asch, S. M. (2009). Improving Latino disaster preparedness using social networks. American Journal of Preventive Medicine, 37, 512-517. https://doi .org/10.1016/j.amepre.2009.07.022

Eisenman, D., Chandra, A., Fogleman, S., Magana, A., Hendricks, A., Wells, 
K.,... Plough, A. (2014). The Los Angeles County community disaster resilience project-a community-level, public health initiative to build community disaster resilience. International Journal of Environmental Research and Public Health, 11, 8475-849o. https://doi.org/10.339o/ijerph110808475 Falconi, M., Fahim, C., \& O’Sullivan, T. (2012). Protecting and supporting high risk populations in pandemic: Drawing from experiences with influenza A ( $\left.\mathrm{H}_{1} \mathrm{~N}_{1}\right)$. International Journal of Child Health and Human Development, 5, 373-381. Retrieved from ProQuest database.

Glik, D. C., Eisenman, D. P., Zhou, Q., Tseng, C.-H., \& Asch, S. M. (2014). Using the Precaution Adoption Process model to describe a disaster preparedness intervention among low-income Latinos. Health Education Research, 29, 272-282. https://doi.org/10.1093/her/cyt109

Heath, R. L., Lee, J., \& Ni, L. (2009). Crisis and risk approaches to emergency management planning and communication: The role of similarity and sensitivity. Journal of Public Relations Research, 21, 123-142. https://doi .org/10.1080/10627260802557415

Jahangiri, K., Izadkhah, Y. O., Montazeri, A., \& Hosseini, M. (2010). People’s perspectives and expectations on preparedness against earthquakes: Tehran case study. Journal of Injury and Violence Research, 2, 85-91. https://doi .org/10.5249/jivr.v2i2.25

Kapucu, N. (2008). Collaborative emergency management: Better community organizing, better public preparedness and response. Disasters, 32, 239-232. https://doi.org/10.1111/j.1467-7717.2008.01037.x

Karan, K., Aileen, L., \& Elaine, P. Y. L. (2007). Emerging victorious against an outbreak: Integrated communication management of SARS in Singapore. Journal of Creative Communication, 2, 383-403. https://doi.org/10.1177 /097325860700200307

Linnell, M. (2014). Citizen response in crisis: Individual and collective efforts to enhance community resilience. Human Technology, 10, 68-94. https:// doi.org/10.17011/ht/urn.201411203311

Masuda, J. R., \& Garvin, T. (2006). Place, culture, and the social amplification of risk. Risk Analysis, 26, 437-454. https://doi.org/10.1111/j.1539 -6924.2006.00749.x

McComas, K. A. (2003). Citizen satisfaction with public meetings used for risk communication. Journal of Applied Communication Research, 31, 164-184. https://doi.org/10.1080/0090988032000064605 
Mei, E. T. W., Lavigne, F., Picquout, A., de Belizal, E., Brunstein, D., Grancher, D., ... Vidal, C. (2013). Lessons learned from the 2010 evacuations at Merapi volcano. Journal of Volcanology and Geothermal Research, 261, 348-365. https://doi.org/10.1016/j.jvolgeores.2013.03.010

Mitchell, T., Haynes, K., Hall, N., Choong, W., \& Oven, K. (2008). The roles of children and youth in communicating disaster risk. Children, Youth, and Environments, 18, 254-279. https://www.jstor.org/stable/10.7721/chily outenvi.18.1.0254

Muttarak, R., \& Pothisiri, W. (2013). The role of education on disaster preparedness: Case study of 2012 Indian Ocean earthquakes on Thailand's Andaman Coast. Ecology and Society, 18(4), 51. https://doi.org/10.5751 /ES-06101-180451

Nepal, V., Banerjee, D., Slentz, M., Perry, M., \& Scott, D. (2010). Communitybased participatory research in disaster preparedness among linguistically isolated populations: A public health perspective. Journal of Empirical Research Ethics, 5, 53-63. http://www.jstor.org/stable/10.1525/jer.2010.5.4.53 Paek, H.-J., Hilyard, K., Freimuth, V., Barge, J. K., \& Mindlin, M. (2010). Theorybased approaches to understanding public emergency preparedness: Implications for effective health and risk communication. Journal of Health Communication, 15, 428-444. https://doi.org/10.1080/10810731003753083

Perko, T., van Gorp, B., Turcanu, C., Thijssen, P., \& Carle, B. (2013). Communication in nuclear emergency preparedness: A closer look at information reception. Risk Analysis, 33, 1987-2001. https://doi.org/10.1111/risa.12048

Perry, R. W., \& Lindell, M. K. (2008). Volcanic risk perception and adjustment in a multi-hazard environment. Journal of Volcanology and Geothermal Research, 172, 170-178. https://doi.org/10.1016/j.jvolgeores.2007.12.006

Prior, T., \& Paton, D. (2008). Understanding the context: The value of community engagement in bushfire risk communication and education: $\mathrm{Ob}-$ servations following the East Coast Tasmania bushfires of December 2006. Australasian Journal of Disaster and Trauma Studies, 2. Retrieved from http://www.massey.ac.nz/ trauma/

Roder, G., Ruljigaljig, T., Lin, C.-W., \& Tarolli, P. (2016). Natural hazards knowledge and risk perception of Wujie indigenous community in Taiwan. Natural Hazards, 81, 641-662. https://doi.org/10.1007/s11069-015-2100-4 Roess, A. A., Monroe, B. P., Kinzoni, E. A., Gallagher, S., Ibata, S. R., Badinga, N., ... Reynolds, M. G. (2011). Assessing the effectiveness of a community 
intervention for Monkeypox prevention in the Congo Basin. PLoS Neglected Topical Disease, 5, e1356. https://doi.org/10.1371/journal.pntd.0o01356 Serra, A., Tabara, J. D., \& Chabay, I. (2011). Assessing the role of vertical and horizontal communication in disaster risk reduction learning and planning: The case of the Spanish Tous dam-break, 1982. Retrieved from the United Nations Office for Disaster Risk Reduction website: http://www.unisdr .org/files/18197_204chabayetal.assessingtheroleofver.pdf

Shenhar, G., Rozenfeld, M., Radomislensky, I., \& Peleg, K. (2016). Comparison of two successive earthquake awareness campaigns in Israel: Improved methodology or a cumulative effect? Disaster Medicine and Public Health Preparedness, 10, 74-79. https://doi.org/10.1017/dmp.2015.95

Strawderman, L., Salehi, A., Babski-Reeves, A., Thomton-Neaves, T., \& Crosby, A. (2012). Reverse 911 as a complementary evacuation warning system. Natural Hazards Review, 13, 65-73. https://doi.org/10.1061/(ASCE)NH.1527 $-6996.0000059$

Terpstra, T. (2011). Emotions, trust, perceived risk: Affective and cognitive routes to flood behavior. Risk Analysis, 31, 1658-1675. https://doi.org/10.1111 /j.1539-6924.2011.01616.x

Tuerk, P. W., Hall, B., Nagae, N., McCauley, J. L., Yoder, M., Rauch, S. A. M., ... Dussich, J. (2013). Forty days after the great East Japan earthquake: Field research investigating community engagement and traumatic stress screening in a post-disaster community mental health training. International Journal of Psychiatry in Medicine, 45, 159-174. http://doi.org/10.219o /PM.45.2.e

Winters, C. A., Kuntz, S. W., Weinert, C., \& Black, B. (2014). A case study exploring research communication in a rural community experiencing an environmental disaster. Applied Environmental Education and Communication, 13, 213-226. https://doi.org/10.1080/1533015X.2014.970718 Yen, M., Wu, T. J., Chiu, A. W., Wong, W., Wang, P., Chan, T., \& King, C. (2009). Taipei's use of a multi-channel mass risk communication program to rapidly reverse an epidemic of highly communicable disease. PLoS One, 4(11), e7962. https://doi.org/10.1371/journal.pone.0007962 


\section{Other UN Languages Studies*}

\section{Arabic}

السيد، هالة. (ץ+1・). دور المجالس الشعبية المحلية في إدارة الأزمات والكوارث المجتمعية : دراسة مطبقة على المجلس

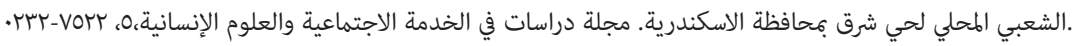
[Al-Sayed, H. (2010). The role of local councils in crisis and community disaster management: An application to the local people's assembly in East Alexandria. Journal of Social Work Studies and Humanities, 5, 2257-2320.] .الشهري، نوح. (r.اع). أزمة التعامل مع المقيمين غير الشرعيين دراسة حالة. رسالة الماجستير

[Al-Shahri, N. (2014). Management of illegal aliens: Case study (Unpublished master's thesis). Naif Arab University for Security Sciences.]

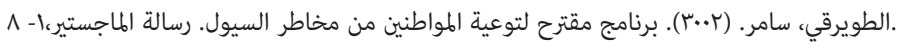

[Al-Tuwairqi, S. (2003). A proposed program to educate citizens about the risk of floods (Unpublished master's thesis). Naif Arab University of Security Sciences.]

لطف الله، نادية. (ץ.ا•). فاعلية وحدة عه الأمراض البائية في ضىء المعايير القمية في تيمية المعارف ومهارات إدارة

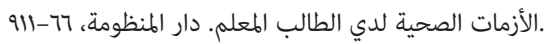

[LutfAllah, N. (2010). Effectiveness of the infectious diseases unit in the light of national standards in knowledge development knowledge and skills of health crisis management amongst students and teachers. Dar Al Manduma, 66-119.]

عودة، عبد الله. (ץ.1). متطلبات بناء القدرات المؤسسية للجمعيات الأهلية لمواجهة كارثة السيول بأسوان: دراسة

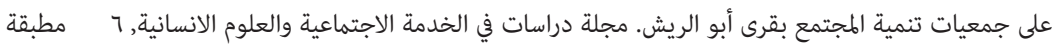
$979 \%-\cdot 1 \cdot \varepsilon,(\Lambda r)$.

[Ouda, A. (2010). Institutional requirements of community associations to manage the flood disaster in Aswan: An application to community development associations in the villages of Abu Rish. Journal of Social Work Studies and Humanities, 6, 3969-4010.]

زهرزهران، هيام. (r..7). دور الجمعيات الأهلية في التعامل مع المشكلات القومية في ضوء متطلبات المجتمع المعاصر دراسة مطبقة على جمعية الرعاية المتكاملة بعين حلوان ومشكلة انفلونزا الطيور. مجلة دراسات في الخدمة الاجتماعية

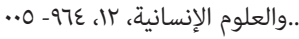

* The sources in other UN languages were read in the original language by Wayne State University graduate students: Fatima A. Barakji, Javier B. Guzman-Barcenas, Juan Liu, Beth N. Fowler Mail, Anna Nagayko, and Jacob J. Nickell. They translated the reference into APA style format, thus in brackets, and the article content for the research team. 
[Zahran, H. (2006). Role of local associations in dealing with national problems in the light of the requirements of contemporary society: A study applied to the Integrated Care Society in Helwan during $\mathrm{H}_{5} \mathrm{~N}_{1}$ crisis. Journal of Social Work Studies and Humanities, 21, 469-500.]

\section{Chinese}

陆剑云, 李美霞, 冯晶. (2010). 风险沟通对甲型 $\mathrm{H}_{1} \mathrm{~N}_{1}$ 流感病例密切接触 者心理状况的影响. 热带医学杂志. 10(6), 735-737.

[Lu, J., Li, M, \& Feng, J. (2010). Examining the influence of risk communication to the psychological status of people in the $\mathrm{A} \mathrm{H}_{1} \mathrm{~N}_{1}$ Quarantine Center. Medicine, 10(6), 735-737.]

苏桂武, 马宗晋, 等. (2008). 汶川地震灾区民众认知与响应地震灾害的特 点及其减灾宣教意义, 以四川省德阳市为例. 地震地质. 30, 877-891. [Su, G., Ma, Z., et al. (2008). Examining the characteristics of people's response to and perception of Wenchuan earthquake: Case study of Deyang city in Sichuang Province. Seismology and Geology, 30, 877-891.]

\section{French}

Affletranger, B., \& de Richemond, N. M. (2003). Gestion de l'alerte et de l'information lors des crues: conditions et limites d'une démarche participative locale. L'exemple des Deux-Sèvres. Flux, 1, 16-27.

[Affletranger, B., \& de Richemond, N. M. (2003). Management of warning and information during floods: Conditions and limitations of a local participatory approach. The example of Deux-Sèvres. Flux, 1, 16-27. https:// doi.org/10.3917/flux.051.0016]

Baggio, S., \& Rouquette, M. L. (2006). La représentation sociale de l'inondation: influence croisée de la proximité au risque et de l'importance de l'enjeu. Bulletin de psychologie, 481, 103-117.

[Baggio, S., \& Rouquette, M. L. (2006). Social representation of flooding: How proximity influences risk and its importance. Psychology Bulletin, 481, 103-117. https://doi.org/10.3917/bupsy.481.0103]

Bouzouki, S. A. O. (2006). L'auto organisation de la population en situation de crise. Risques, 66, 172-180.

[Bouzouki, S. A. O. (2006). Self-organization of populations in times of crisis. Risks, 66, 172-180. Retrieved from https://hal.laas.fr/UR2-HB/halshs -00350869v1] 
Chahraoui, K., Laurent, A., Colbeau-Justin, L., Weiss, K., \& de Vanssay, B. (2003). Stress psychologique des sinistrés des inondations de la Somme: une étude exploratoire. L'Information Psychiatrique, 79, 307-318.

[Chahraoui, K., Laurent, A., Colbeau-Justin, L., Weiss, K., \& de Vanssay, B. (2003, April). Psychological stress of those affected by floods in the Somme: An exploratory study. Psychiatric Information, 79, 307-318. Retrieved from http://www.jle.com/fr/revues/ipe/sommaire.phtml?cle_parution=777]

D'Ercole, R. (2002). Forces et faiblesses de la gestion des risques au Japon: une réflexion à partir de la crise liée à l'éruption du volcan Usu (Hokkaidô) de 2000. Annales de Géographie, 111, 524-548.

[D'Ercole, R. (2002). Forces and weaknesses of the risk management in Japan: A reflexion after the crisis provoked by the Usu, Hokkaidô eruption in 2000. Annals of Geography, 111, 524-548. Retrieved from https://www .jstor.org/stable/23455976]

Duchêne, F., \& Journel, C. M. (2004). Lexperience de la crue. Annales de la recherche urbaine, 95, 71-77.

[Duchêne, F., \& Journel, C. M. (2004). Experience of the flood. Annals of Urban Research, 95, 71-77.]

Erlich, M., Sauvaget, P., \& Taliercio, G. (2000). L'évolution des systèmes de prévision des crues et des inondations: de l'offre technique vers une offre de service au citoyen. Réflexions et perspectives. La Houille Blanche, 1, 64-72.

[Erlich, M., Sauvaget, P., \& Taliercio, G. (200o). The evolution of flood and flood forecasting systems: What technology can offer to citizens. Reflections and perspectives. The White Coal, 1, 64-72. https://doi.org/10.1051 /lhb/200ooo9]

Gaillard, J. C. (2002, September). Implications territoriales et ethnoculturelles d'une crise volcanique: le cas de l'éruption du Mont Pinatubo aux Philippines. Annales de géographie, 111, 574-591.

[Gaillard, J. C. (2002). Territorial and ethno-cultural implications of a volcanic crisis: The Mount Pinatubo (Philippines) 1991 eruption. Annals of Geography, 111, 574-591. https://doi.org/10.3406/geo.2002.21620]

Gaillard, J. C., Liamzon, C. C., \& Maceda, E. A. (2008). Catastrophes dites «naturelles» et développement: réflexions sur l'origine des désastres aux Philippines. Revue Tiers Monde, 2, 371-39o.

[Gaillard, J. C., Liamzon, C. C., \& Maceda, E. A. (2008). Catastrophes considered "natural" and development: Reflections on the origin of disasters 
in the Philippines. Third World Review, 2, 371-39o. Retrieved from http:// www.jstor.org/stable/23593288]

Glatron, S. (2009). Representations cognitives et spatiales des risques et des nuisances pour les citadins (Unpublished doctoral dissertation). Universite de Strasbourg.

[Glatron, S. (2009). Cognitive and spatial representations of risks and nuisances for city dwellers (Unpublished doctoral dissertation). University of Strasbourg. Retrieved from https://tel.archives-ouvertes.fr/tel-0056 5920]

Gondard-Delcroix, C., \& Rousseau, S. (2004). Vulnérabilité et stratégies du rables de gestion des risques: Une étude appliquée aux ménages ruraux de Madagascar. Développement durable et territoires. Économie, géographie, politique, droit, sociologie, 3 .

[Gondard-Delcroix, C., \& Rousseau, S. (2004). Vulnerability and sustainable risk management strategies: Study of rural households in Madagascar. Sustainable Territorial Development, 3. https://doi.org/10.400o/developpe mentdurable.114]

Heitz, C., \& Glatron, S. (2013). Outils d'information du public sur les risques majeurs: les cartes sont-elles un vecteur d'acculturation? Étude exploratoire de la perception de cartes de risque d'inondations par les individus exposés (Eurométropole de Strasbourg).

[Heitz, C., \& Glatron, S. (2013). Informational public tools on major risks: Are the maps vector acculturation? Exploratory study of the perception of flood maps by individuals at risk (Eurometropole of Strasbourg). Retrieved from https://www.sfer.asso.fr/source/jrss2015/jrss2015_heitz.pdf]

Royaume du Maroc, Ministère de l'Aménagement du Territoire, de l'Eau et de l'Environnement Département de l'Environnement. (2005). Rapport national sur la prevention des desastres conference de Kobe-Hyogo.

[Kingdom of Morocco, Minister of Planning, Water and the Environment, Department of the Environment. (2005). National report on the KobeHyogo conference of disaster prevention. Retrieved from https://www.unisdr .org/2005/mdgs-drr/national-reports/Morocco-report.pdf]

Maret, I., \& Cadoul, T. (2008, November). Résilience et reconstruction durable: que nous apprend La Nouvelle-Orléans? Annales de géographie, 117, 104-124.

[Maret, I., \& Cadoul, T. (2008). Resilience and sustainable reconstruction: 
What can New Orleans teach us? Annals of Geography, 117, 104-124. Retrieved from http://www.jstor.org/stable/23457742]

Rode, S. (2008). La prévention du risque d'inondation, facteur de recomposition urbaine? L'Information géographique, 72(4), 6-26.

[Rode, S. (2008). Prevention of the risk of flooding under urban restructuring? Geographic Information, 72(4), 6-26. Retrieved from https://www.cairn .info/revue-1-information-geographique-2008-4-page-6.htm]

Setbon, M., \& Raude, J. (2009). Le chikungunya à la Réunion: facteurs sociaux, environnementaux et comportementaux en situation épidémique. Population, 63, 555-583.

[Setbon, M., \& Raude, J. (2008). Chikungunya in Réunion: Social, environmental, and behavioural factors in an epidemic. Population, 63, 555-583. Retrieved from http://www.jstor.org/stable/20451115]

Tamru, B. (2002, September). Lémergence du risque d'inondation à AddisAbeba: pertinence d'une étude des dynamiques urbaines comme révélatrices d'un processus de vulnérabilisation. Annales de géographie, 111, 614-636.

[Tamru, B. (2002). The rise of flood risk in Addis-Ababa: The relevance of the study of urban dynamics as an indicator of the vulnerability process. Annals of Geography, 111, 614-636. Retrieved from http://www.jstor.org /stable/23455980]

Organisation mondiale de la Sante. (2004). Instauration d'un dialogue sur les risques dus aux champs électromagnétiques.

[World Health Organization. (2004). Establishment of a dialogue on risks from electromagnetic fields. Geneva, Switzerland: Author.]

United Nations Food and Agriculture Organization and World Health Organization. (2011). FAO/WHO guide for the implementation of the principles and procedures of risk analysis in food safety emergencies. Retrieved from http:// apps.who.int/iris/bitstream/handle/10665/78041/9789242502473_fre.pdf

Vinet, F., \& Meschinet de Richemond, N. (2005). Territoires et acteurs du risque d'inondation torrentielle en France méditerranéenne. Bulletin de l'Association de géographes français, 82, 116-126.

[Vinet, F., \& Meschinet de Richemond, N. (2005). Territories and actors of flash flood hazard in French Mediterranean area. Bulletin of the Association of French Geographers, 82, 116-126. Retrieved from http://biblio.uqar.ca /archives/30376470part1.pdf] 


\section{Russian}

Дурнев, Р. А., \& Скубак, Н. Ю. (2008). Информирование и оповещение населения: некоторые особенности восприятия информационных сообщений. Технологии гражданской безопасности, 5(4), 57-64.

[Durnev, R. A., \& Skubak, N. Y. (2008). Information and notification of population: Some peculiarities of information perception. Civil Security Technologies, 5(4), 57-64.]

Габричидзе, Т. Г. (2013). Трагедия в Крымске: выводы и предложения по обеспечению безопасности. Вектор науки ТГУ, 3, 118-12о.

[Gabrichidze, T. G. (2013). Tragedy in Krymsk: Conclusions and suggestions on providing security. TSU Vector of Science, 3, 118-120.]

Кутовая, С. В. (2014). Наводнение 2013 года. Социальное самочувствие эвакуированных жителей. Четвертые областные РАДДЕВСКИЕ ЧТЕНИЯ.

[Kutovaya, S. V. (2014). Flood 2013: Social well-being of the evacuated residents. Paper presented at the 4th Regional Reddevkiy Readings Conference.] Подкорытов, Н. С. (2014). Информирование населения как один из способов предупреждения причинения вреда. Проблемы науки, 1-3. [Podkorytov, N. S. (2014). Informing population as a way to avoid harm. Science Problems, 2, 97-100. Retrieved from https://3minut.ru/images /PDF/2015/2.pdf\#page=97]

\section{Spanish}

Coronado Salas, C., Diaz-Barriga, F., Moreno Sanchez, A., Carrizalez Yanez, L., Torres Nerio, R., Renteria Guzman, Y., \& Cubillas Tejeda, A. (2012). La comunicación de riesgos como una herramienta para disminuir la exposición infantil a plomo y arsénico en la zona contaminada de Villa de la Paz-Matehuala, San Luis Potosí, México. Rev. Int. Contam. Ambie., 28(2), 167-181.

[Coronado Salas, C., Diaz-Barriga, F., Moreno Sanchez, A., Carrizalez Yanez, L., Torres Nerio, R., Renteria Guzman, Y., \& Cubillas Tejeda, A. (2012). Risk communication as tool to decrease infant lead and arsenic exposure in the contaminated area of Villa De La Paz, San Luis Potosí, Mexico. International Contamination and Environmental Journal, 28(2), 167-181. Retrieved from http://www.scielo.org.mx/scielo.php?script=sci_arttext\&pid $=$ So188-49992012000200008] 
Francescutti, P. (2007). De las vacas locas a la gripe aviar: La comunicación del riesgo en España. In J. R. Gomez (Ed.), El riesgo en la sociedad de la información (pp. 41-59). Retrieved from http://ruc.udc.es/dspace/bitstream /handle/2183/12807/CC-91_art_3.pdf

[Francescutti, P. (2007). From cow disease to SARS: Risk communication in Spain. In J. R. Gomez (Ed.), Risk within information society (pp. 41-59). Retrieved from https://core.ac.uk/download/pdf/61911483.pdf]

\section{Existing Reviews}

Gurabardhi, Z., Gutteling, J. M., \& Kuttschreuter, M. (2005). An empirical analysis of communication flow, strategy and stakeholders' participation in the risk communication literature. Journal of Risk Research, 8, 499-511. https://doi.org/10.1080/13669870500064192

Lettieri, E., Masella, C., \& Radaelli, G. (2009). Disaster management: Findings from a systematic review. Disaster Prevention and Management, 18, 117-136. https://doi.org/10.1108/09653560910953207

Levac, J., Toal-Sullivan, D., \& O'Sullivan, T. L. (2012). Household emergency preparedness: A literature review. Journal of Community Health, 37, 725-733. https://doi.org/10.1007/s10900-011-9488-x

McCaffrey, S. (2015). Community wildfire preparedness: A global state-of-theknowledge summary of social science research. Current Forestry Report, 1, 81-90. https://doi.org/10.1007/s40725-015-0015-7

Savoia, E., Lin, L., \& Viswanath, K. (2013). Communications in public health emergency preparedness: A systematic review of the literature. Biosecurity and Bioterrorism: Biodefense Strategy, Practice, and Science, 11, 170-184. https://doi.org/10.1089/bsp.2013.0038

Schiavo, R., Leung, M. M., \& Brown, M. (2014). Communicating risk and promoting disease mitigation measures in epidemics and emerging disease settings. Pathogens and Global Health, 108, 76-94. https://doi.org/10.1179 /2047773214Y.0000000127

Wachinger, G., Renn, O., Begg, C., \& Kuhlicke, C. (2013). The risk perception paradox-Implications for governance and communication of natural hazards. Risk Analysis, 33, 1049-1063. https://doi.org/10.1111/j.1539 -6924.2012.01942.x 


\section{Other References}

Alonso-Coello, P., Schünemann, H. J., Moberg, J., Brignardello-Petersen, R., Akl, E. A., Davoli, M., Treweek, S., Mustafa, R. A.,... Oxman, A. D. (2016). GRADE Evidence to Decision (EtD) frameworks: A systematic and transparent approach to making well informed healthcare choices. 1: Introduction. BMJ, 353, i2016. https://doi.org/10.1136/bmj.i2016

Barnett-Page, E., \& Thomas, J. (2009). Methods for the synthesis of qualitative research: A critical review. BMC Medical Research Methodology, 9, 59. https://doi.org/10.1186/1471-2288-9-59

GRADE Working Group. (2004). Grading quality of evidence and strength of recommendations. BMJ, 328, 1490-1494.

Guyatt, G., Oxman, A. D., Aki, E. A., Kunz, R., Vist, G., Brozek, J., .. Schunemann, H. J. (2011). GRADE guidelines: 1. Introduction-GRADE evidence profiles and summary of findings table. Journal of Clinical Epidemiology, 64, 383-394. https://doi.org/10.1016/j.jclinepi.2010.04.026

Lewin, S., Glenton, C., Munthe-Kaas, H., Carlsen, B., Colvin, C. J., Gulmezoglu, M.,... Rashidian, A. (2015). Using qualitative evidence in decision making for health and social interventions: An approach to assess confidence in findings from qualitative evidence syntheses (GRADE-CERQual). PLOS Medicine. https://doi.org/10.1371/journal.pmed.1001895

Pope, C., Ziebland, S., \& Mays, N. (2000). Analysing qualitative data. BMJ, 320, 114-116.

Tyndall, J. (2008). How low can you go? Towards a hierarchy of grey literature. Paper presented at Dreaming 08: Australian Library and Information Association Biennial Conference, Alice Springs, September. Retrieved from http://hdl.handle.net/2328/3326

\section{Acknowledgments}

This project was funded by the World Health Organization, Department of Communications (contract PO 201393190, WHO registration 2015/586494-O, and contract PO 201428650, WHO registration 2016/601521-0). 
Julie M. Novak, $\mathrm{PhD}$, is an associate professor in the Department of Communication at Wayne State University. Her research focuses on sensemaking and co-constructions of experiences in applied intersections of health, risk, and crisis communication.

Ashleigh M. Day is a doctoral candidate in the Department of Communication at Wayne State University. She earned her master of arts degree in applied communication from Northern Arizona University. Her research interests center on crisis, risk, and health communication. In particular, she is interested in the ways that people receive, seek out, and process communication to facilitate decision-making and sensemaking of their experience with crisis or risk.

Pradeep Sopory, PhD, conducts research on message design and effects, especially in the context of health communication. His two areas of research are (a) metaphor use in persuasive messages and (b) risk communication, particularly in the context of health-related attitudes, beliefs, and behaviors. He has been the principal investigator of several research grants investigating basic message effects processes in both laboratory and field settings.

Lee Wilkins, $\mathrm{PhD}$, is a professor emerita at Wayne State University. Her research focuses on media coverage of hazards and disasters and media ethics. She is also a Curator's Distinguished Teaching Professor at the University of Missouri, School of Journalism and an emeritus professor at that institution.

Donyale Padgett, $\mathrm{PhD}$, is a critical scholar concerned with the generative power of rhetoric in the public sphere, which has to do with how groups use persuasion and dialogue to gain influence. Much of her work is concerned with how people from traditionally marginalized groups relate to power in social structures, deal with oppression, and negotiate their identities within institutions.

Stine Eckert, $\mathrm{PhD}$, is an assistant professor in the Department of Communication at Wayne State University. Her research focuses on the 
intersection of social media, minorities, and gender and the democratic potential of social media and international comparative work. She is chair of the Feminist Scholarship Division of the International Communication Association and cofounder of Wikid GRRLs.

Jane Noyes, $\mathrm{PhD}$, is professor of health and social care services research and child health at Bangor University, United Kingdom. She is interested in health services research and evidence synthesis, in particular in evidence synthesis methodology. She is lead convener of the Cochrane Qualitative and Implementation Methods Group, co-chair of the Cochrane Methods Executive, and member of the Cochrane Scientific Committee.

Tomas Allen is a librarian for over 15 years within the World Health Organization. Tomas's current responsibilities in the WHO Library include reference, in-depth searching, historical research, and training (both local and regional). Tomas is originally from Manitoba, Canada, and has a master's of library and information studies degree from McGill University (Montreal).

Nyka Alexander is a communications officer with WHO, where she manages the team that covers emergencies for the organization. She has been deployed to emergencies for over a decade, covering typhoons, earthquakes, and outbreaks from cholera to plague to Ebola. She is a former broadcast journalist and holds a bachelor's degree in physics and a master's degree in international affairs and journalism.

Marsha Vanderford, $\mathrm{PhD}$, provides strategic communication support to national and international public agencies, including the U.S. CDC, the WHO, the FAO, the Task Force for Global Health, and the Warning Project. She serves as a temporary technical advisor to WHO related to risk communication aspects of the International Health Regulations. Dr. Vanderford served as director of communications at WHO (2016-2017) and in several leadership roles at the CDC (2000-2015), including associate director for communications, Center for Global Health, and director of the CDC's Emergency Risk Communication Branch. 
Gaya Gamhewage, MD, is the manager of the Support for Response Unit of the Infectious Hazard Management Department of the WHO Health Emergencies Programme based in Geneva, Switzerland. Dr. Gamhewage has 17 years of experience at WHO working in a range of high-profile roles, mostly in humanitarian and epidemic and pandemic capacity building and response.

\section{ORCID}

Julie M. Novak (D) https://orcid.org/oooo-0oo1-5536-6171

\section{References}

Centers for Disease Control and Prevention. (2014). CERC manual. Retrieved from https://emergency.cdc.gov/cerc/manual/index.asp

Centers for Disease Control and Prevention. (2018). CERC manual. Retrieved from https://emergency.cdc.gov/cerc/manual/index.asp

Critical Appraisal Skills Programme. (2013). CASP qualitative checklist. Retrieved from http://www.casp-uk.net/casp-tools-checklists

Davids, E. L., \& Roman, N. V. (2014). A systematic review of the relationship between parenting styles and children's physical activity. African Journal for Physical, Health Education, Recreation, and Dance, 20, 228-246. Retrieved from https://hdl.handle.net/10520/EJC162511

Effective Practice and Organisation of Care. (2015). Suggested risk of bias criteria for EPOC reviews. Retrieved from http://epoc.cochrane.org/epoc -specific-resources-review-authors

Higgins, J. P. T., \& Green, S. (Eds.). (2011). Cochrane handbook for systematic reviews of interventions (Version 5.1.0, updated March 2011). Retrieved from http://www.handbook.cochrane.org

Lettieri, E., Masella, C., \& Radaelli, G. (2009). Disaster management: Findings from a systematic review. Disaster Prevention and Management, 18, 117-136. https://doi.org/10.1108/09653560910953207

Levac, J., Toal-Sullivan, D., \& O'Sullivan, T. L. (2012). Household emergency preparedness: A literature review. Journal of Community Health, 37, 725-733. https://doi.org/10.1007/s1090o-011-9488-X

McCaffrey, S. (2015). Community wildfire preparedness: A global state-of-the- 
knowledge summary of social science research. Current Forestry Report, 1, 81-9o. https://doi.org/10.1007/s40725-015-0015-7

Noyes, J., Booth, A., Lewin, S., Carlsen, B., Glenton, C., Munthe-Kaas, H., ... Tucker, J. D. (2019). Applying the GRADE-CERQual approach: Making a CERQual assessment of relevance of the data. Unpublished manuscript.

Pluye, P., Robert, E., Cargo, M., Bartlett, G., O'Cathain, A., Griffiths, F., ... Rousseau, M. C. (2011). Proposal: A mixed methods appraisal tool for systematic mixed studies reviews. Retrieved from http://mixedmethods appraisaltoolpublic.pbworks.com

Shea, B. J., Grimshaw, J. M., Wells, G. A., Boers, M., Andersson, N., Hamel, C., ... Bouter, L. M. (2007). Development of AMSTAR: A measurement tool to assess the methodological quality of systematic reviews. BMC Medical Research Methodology, 7(1), 10. https://doi.org/10.1186/1471-2288-7-10 World Health Organization. (2018). Communicating risk in public health emergencies: A WHO Guideline for Emergency Risk Communication (ERC) policy and practice. Retrieved from http://www.who.int/risk-communication /guidance/download/en/ 